\title{
Degradation of lignocellulosic matrix of oilseed cakes by solid-state fermentation: fungi screening for enzymes production and antioxidants release
}

\author{
Daniel Sousa, ${ }^{\mathrm{a}} \odot$ José M Salgado, ${ }^{\mathrm{a}} \odot$ Maria Cambra-López, ${ }^{\mathrm{b}}$ \\ Alberto CP Dias' and Isabel Belo ${ }^{a^{*}}$ 。
}

\begin{abstract}
BACKGROUND: Vegetable oils are yearly produced in large amounts generating solid by-products, the oilseed cake (OC). OCs are lignocellulosic materials that have been used for animal feed with some limitations due to high fibre content from the plant cell walls. Biotechnological processes can help to overcome these limitations and contribute to up-grading such by-products, enhancing their nutritional value as feed ingredients.

RESULTS: All fungal species were able to decrease neutral detergent fibre and acid detergent fibre in all by-products. Additionally, relevant enzymes were produced by the three fungi studied resulting in an improved antioxidant capacity of all fermented OCs. Aspergillus niger led to the highest activity of cellulase $\left(109 \mathrm{U} \mathrm{g}^{-1}\right)$, xylanase $\left(692 \mathrm{U} \mathrm{g}^{-1}\right)$ and protease $(157 \mathrm{U} \mathrm{g}$ ) per dry $O C$ matter and to the recovery of an extract rich in antioxidants, with the highest scavenging potential of free radicals and superoxide anion, iron chelation ability and reducing power. Rhyzopus oryzae produced the highest activity of $\beta$-glucosidase $\left(503 \mathrm{U} \mathrm{g}^{-1}\right.$ ) and led to the highest liberation of total phenolic content (TPC). Principal components analysis showed that extracts with high antioxidant potential were obtained in solid-state fermentation (SSF) with high enzymatic activity. A positive correlation was established between the action of $\beta$-glucosidase and TPC.

CONCLUSION: Within the same bioprocess it was possible to improve the nutritional value of OCs and to obtain relevant bioactive compounds such as lignocellulosic enzymes and phenolic compounds with antioxidant potential, resulting in a significant improvement of already valuable by-products with commercial interest for animal feed.

(c) 2021 Society of Chemical Industry.
\end{abstract}

Keywords: sunflower cake; rapeseed cake; soybean cake; lignocellulolytic enzymes; phenolic compounds; filamentous fungi

\section{INTRODUCTION}

According to the latest report of the United Nations, it is expected a global population of 9.73 billion people by 2050 and 11.2 billion people by the end of the century, ${ }^{1}$ implying an increase for food demand and of overall food production.

Vegetable oils are an important part of the human diet as they constitute one of the main sources of calories and energy. Hence, they have an unquestionable role in our daily lives due to their versatility and multiple applications in areas such as the food industry, cosmetics, pharmaceutical and also in the biofuels production. ${ }^{2}$ Soybean (Glycine max), rapeseed (Brassica napus) and sunflower (Helianthus annuus) are the three main sources of oilseed for vegetable oils production. According to the US Department of Agriculture for the 2020/2021 season, global production of soybean, rapeseed and sunflower are expected to reach $361.08,68.73$ and 50.14 million metric tons. ${ }^{3}$

Extraction of vegetable oils entails the production of by-products, and the main ones are solids normally referred as cakes (residue obtained after screw press) or meal if it has suffered any additional process, usually organic solvent de-oiling process. These are characterized by their high protein content and high fraction of structural compounds from plant cell walls including cellulose, hemicellulose, pectin and lignin. ${ }^{4}$

Oilseed cakes (OCs) are traditionally used for animal feed or plant/soil compost. These two options are seen as economically valuable and profitable ways of disposing of by-products without any additional cost and with minimum environmental impact.

\footnotetext{
Correspondence to: I Belo, Centre of Biological Engineering, University of Minho, Campus de Gualtar, 4710-057 Braga, Portugal. E-mail: ibelo@deb. uminho.pt

a Centre of Biological Engineering, University of Minho, Campus de Gualtar, Braga, Portugal

b Institute of Animal Science Technology, Universitat Politècnica de València, Valencia, Spain

c Centre of Molecular and Environmental Biology, University of Minho, Braga, Portugal
}

@ 2021 Society of Chemical Industry.


The abundance of protein, carbohydrates and minerals make these by-products suitable to animal feed. However, relatively high amounts of indigestible fibre fraction and lignin, ${ }^{5}$ may hinder nutrient digestibility in animals.

Due to the volume of OC produced every year and their composition, it is important to explore alternatives that can add value to these by-products, using biotechnological and clean processes. In fact, the chemical composition of OCs, combine the perfect environment for microbial growth. Therefore, it is essential to find ecofriendly approaches to achieve an adequate valorization of these by-products, such as biotechnological processes that may lead to the obtainment of value-added compounds, decreasing environmental impact and creating new business opportunities and workplaces, contributing to the implementation of circular economy in agro-food industries.

OCs are lignocellulosic materials, suitable to be used as substrate in solid-state fermentation (SSF). SSF is defined as a process that occurs in the absence or near absence of free water using a natural or inert substrate as solid support and ensuring enough moisture to support the growth and metabolism of microorganisms. This fermentation mimics conditions close to the natural habitat of many microorganisms of which filamentous fungi are the ones that better adapt to SSF. ${ }^{6}$

Sunflower cake (SFC), rapeseed cake (RSC) and soybean cake (SBC) have high protein content $\left(300-500 \mathrm{~g} \mathrm{~kg}^{-1}\right)$ and total carbon ranges between 450 and $500 \mathrm{~g} \mathrm{~kg}^{-1}$. Lignocellulosic fractions of these by-products can act as inductors or inhibitors of the production of extracellular enzymes in SSF, depending on their concentration. ${ }^{7}$ This complex matrix is recalcitrant to degradation due to the covalent bonds between hemicellulose and lignin established by hydroxycinnamic acids such as ferulic acid. ${ }^{8}$ Phenolic compounds can be found within the matrix of plant cells in different forms: free phenolics, soluble phenolics (conjugated) or insoluble phenolics. Soluble phenolics are normally esterified to soluble compounds with low molecular weight such as carbohydrates, proteins or lipids. ${ }^{9}$ Insoluble phenolics are also known as non-extractable phenolics and remain in the matrix of the residues after extraction of soluble phenolics. These compounds can be found within the cell wall matrix of vegetable cells and can be released by enzymes. ${ }^{10}$ Phenolic compounds have potential health benefits due to their antioxidant properties such as electrophilic scavenging, inhibitors of reactive oxygen species (ROS) and metal ions chelation. Phenolic acids and flavonoids are among the major families of antioxidants present in SFC, RSC and SBC. ${ }^{11}$ Extraction of antioxidant compounds allows their incorporation in industries such as food being used as food additives or functional foods, ${ }^{12}$ in the pharmaceutical industry ${ }^{13}$ once these compounds can reduce the excessive accumulation of free radicals in the body decreasing the prevalence of chronic diseases and they can also have applications in the cosmetics industry for the formulation of antiageing products. ${ }^{14}$

Bioprocessing of SFC, RSC and SBC by SSF allow the liberation of bioactive compounds with potential antioxidant activity, improving their bioavailability. Additionally, SSF allow the production of extracellular hydrolytic enzymes with commercial interest including as supplement in animal feed. ${ }^{15}$

This work describes the use of by-products from the vegetable oils industry, SFC, RSC and SBC as substrate for SSF using three filamentous fungi species. Enzymes, such as cellulases and xylanases were monitored in water extracts of the fermented cakes, as well as total phenolic content (TPC) and antioxidant potential.
In addition, fermented oilseed cakes were characterized to evaluate their nutritive potential to be used in animal feed.

\section{MATERIALS AND METHODS}

\section{Oilseed cakes (OCs)}

Three OCs, SFC, RSC and SBC were used. SFC was provided by Sorgal, S. A., Aveiro - Portugal and RSC and SBC were provided by IBEROL - Sociedade Ibérica de Oleaginosas, SARL, Vila Franca de Xira - Portugal. OCs were dried at $65^{\circ} \mathrm{C}$ for $24 \mathrm{~h}$ and stored in hermetic plastic bags, kept in the dark at room temperature.

\section{Microorganisms}

Three fungi species were used. Rhyzopus oryzae MUM 10.260 and Aspergillus ibericus MUM 03.113 were obtained from Micoteca of University of Minho, Braga, Portugal. Aspergillus niger CECT 2915 was obtained from CECT (Colección Española de Cultivos Tipo, Valencia, Spain). Fungi were cultivated in potato dextrose agar (PDA) plates and stored at $4{ }^{\circ} \mathrm{C}$.

\section{Characterization of unfermented and fermented solid substrates}

OCs were characterized regarding their physico-chemical properties. Initial and post fermentation characterization of OCs was performed to monitor the changes due to the fermentative process. Moisture was calculated by drying the substrates in an oven at $105^{\circ} \mathrm{C}$ during $24 \mathrm{~h}$ until constant weight. Ashes were determined by high temperature treatment at $575^{\circ} \mathrm{C}$ for $2 \mathrm{~h}$ in a muffle. Nitrogen content was analysed by the Kjeldahl method from which crude protein was estimated using a defined factor of 6.25. Carbon was analysed following the method described by Leite et al. ${ }^{7}$ Total lipids were extracted from $0.4 \mathrm{~g}$ of sample using a mixture of chloroform/methanol $(2: 1 ; v / v)$ as extraction solvent. Briefly, the mixture was incubated at room temperature, with constant shaking at $0.5 \times g$ for $1 \mathrm{~h}$. After, lipids were filtered through a glass wool and evaporated to dryness. The lignocellulosic composition (cellulose, hemicellulose and lignin) of by-products was calculated by a quantitative acid hydrolysis as described by Leite et al. $^{7}$ To estimate soluble protein, free sugars, total phenols and enzymatic activity an extraction with water (ratio solid/liquid of $1 \mathrm{~g}$ to $5 \mathrm{~mL}$ ) was performed at $0.5 \times g$ at room temperature with mechanical agitation for $30 \mathrm{~min}$. Following, the extract was filtered through a nylon net and the liquid fraction was centrifuged at $2264 \times g$ for $10 \mathrm{~min}$ at $4{ }^{\circ} \mathrm{C}$. The enzymatic extract was recovered and stored at $-20^{\circ} \mathrm{C}$ until its analysis. Soluble protein was measured by the Bradford method and free sugars were analysed by the 3,5-dinitrosalicylic acid (DNS) method. Total phenols were quantified using the Folin-Ciocalteau method [Commission Regulation (EEC) No. 2676/90]. pH was measured on the moisturized solid using a probe and respective meter (Hanna Instruments edge $^{\circledast}$ HI 2020-02, Woonsocket, Rl, USA).

\section{Antioxidant activity}

Radical scavenging activity was assessed by the DPPH (2,2-diphenyl-1-picrylhydrazyl) method slightly modified as described by Dulf et al., ${ }^{16}$ with adaptation to microplate reader. Briefly, $200 \mu \mathrm{L}$ of diluted sample extracts were mixed with $100 \mu \mathrm{L}$ of a methanolic solution of DPPH $\left(0.5 \mathrm{mmol} \mathrm{L}^{-1}\right)$. The mixtures were kept in the dark at room temperature for $30 \mathrm{~min}$ and then absorbance was measured at $517 \mathrm{~nm}$. The free radical scavenging activity of extracts was expressed as micromoles of Trolox equivalents per gram of dry substrate $\left(\mu \mathrm{mol} \mathrm{g}{ }^{-1}\right)$. 
Iron chelating was evaluated by the iron (II) chelating ability (ICA) method, performed as described by Oliveira et al. ${ }^{17}$ Extract's chelation ability was expressed as EDTA (ethylenediaminetetraacetic acid) equivalents (in $\mathrm{nmol} \mathrm{g}^{-1}$ ).

Superoxide radical scavenging activity was determined using the PMS-NADH non-enzymatic assay. ${ }^{17}$ The scavenging activity of the extracts was expressed as micromoles of ascorbic acid equivalents per gram of dry substrate $\left(\mu \mathrm{mol} \mathrm{g}{ }^{-1}\right)$.

Ferric reducing ability of plasma (FRAP) was performed according to Fernandes et al. $^{18}$ The reducing ability of extracts was expressed as micromoles of ferrous equivalents per gram of dry substrate $\left(\mu \mathrm{mol} \mathrm{g}{ }^{-1}\right)$.

\section{Hydration properties}

Water holding capacity (WHC) was analysed as according to Raghavendra et al. ${ }^{19}$ WHC was quantified by hydrating $1 \mathrm{~g}$ of dry sample with $30 \mathrm{~mL}$ of distilled water. The mixture was kept at room temperature for $18 \mathrm{~h}$ with stirring. The suspension was filtered, and the hydrated solid was dried at $105^{\circ} \mathrm{C}$ for $2 \mathrm{~h}$ to obtain the residual dry weight. Values were expressed as gram of water per gram of dry solid.

\section{Solid-state fermentation (SSF) of oilseed cake (OC)}

SFC, RSC and SBC were used as substrate in SSF experiments to evaluate the effect of three fungi species, $R$. oryzae, $A$. ibericus and $A$. niger. SSF was carried out in $500 \mathrm{~mL}$ Erlenmeyer flasks with $10 \mathrm{~g}$ of dry substrate. Moisture was adjusted to $750 \mathrm{~g} \mathrm{~kg}^{-1}$ (wet basis) with distilled water. Erlenmeyer flasks with the substrates were sterilized at $121{ }^{\circ} \mathrm{C}$ for $15 \mathrm{~min}$. For inoculation, the fungi grown on PDA for 7 days were suspended in a sterile solution ( $1 \mathrm{~g} \mathrm{~L}^{-1}$ peptone and $0.1 \mathrm{~g} \mathrm{~L}^{-1}$ Tween 80 ) and adjusted to a spore concentration of $10^{6}$ spores $\mathrm{mL}^{-1}$. Each substrate was inoculated with $2 \mathrm{~mL}$ spore suspension and incubated at $25^{\circ} \mathrm{C}$ for 7 days. A control experiment was performed at the same SSF conditions but without inoculation. Each experiment was performed in duplicate.

\section{Enzymatic activities}

Cellulase (endo-1,4- $\beta$-glucanase) was determined using carboxymethylcellulose (CMC) as substrate. Briefly, $250 \mu \mathrm{L}$ of $20 \mathrm{~g} \mathrm{~L}^{-1}$ cellulase substrate in $0.1 \mathrm{~mol} \mathrm{~L}^{-1}$ sodium acetate buffer, $\mathrm{pH} 4.8$ was mixed with the same volume of enzyme containing sample. After enzymatic hydrolysis, reducing sugars were quantified by the DNS method. One unit of enzyme activity was defined as the amount of enzyme required to release $1 \mu \mathrm{mol}$ of glucose reducing sugar equivalents from $\mathrm{CMC}$ in $1 \mathrm{~min}$ at $50{ }^{\circ} \mathrm{C}$ and $\mathrm{pH} 4.8$. The values of cellulase activity were expressed in units per gram of dry substrate $\left(\mathrm{U} \mathrm{g}^{-1}\right)$.

The procedure to determine xylanase activity was the same as described for cellulase activity but the substrate solution used was xylan from beechwood (in $\mathrm{g} \mathrm{L}^{-1}$ ) and the reaction time was $15 \mathrm{~min}$ instead of $30 \mathrm{~min}$. One unit of enzyme activity was defined as the amount of enzyme required to release $1 \mu \mathrm{mol}$ of xylose reducing sugar equivalents from beechwood xylan in $1 \mathrm{~min}$ at $50{ }^{\circ} \mathrm{C}$ and $\mathrm{pH}$ 4.8. The values of xylanase activity were expressed in units per gram of dry substrate $\left(\mathrm{U} \mathrm{g}^{-1}\right)$.

$\beta$-Glucosidase activity was determined using $p$-nitrophenyl- $\beta$-Dglucopyranoside (PNG) as substrate. In test tubes, $100 \mu \mathrm{L}$ of $4 \mathrm{mmol} \mathrm{L}^{-1}$ PNG was mixed with $100 \mu \mathrm{L}$ of sample in citrate buffer $0.05 \mathrm{~N} \mathrm{pH} 4.8$. The tubes were placed on a bath at $50{ }^{\circ} \mathrm{C}$ for $15 \mathrm{~min}$. After $15 \mathrm{~min}$, the tubes were transferred to an ice bath to cool down and then $600 \mu \mathrm{L}$ of sodium carbonate $\left(\mathrm{Na}_{2} \mathrm{CO}_{3}\right.$,
$1 \mathrm{~mol} \mathrm{~L}^{-1}$ ) and $1.7 \mathrm{~mL}$ of distilled water were added. One unit of enzyme activity was defined as the amount of enzyme required to liberate $1 \mu \mathrm{mol}$ of $p$-nitrophenol in $1 \mathrm{~min}$ at $50^{\circ} \mathrm{C}$ and $\mathrm{pH} 4.8$. The values of $\beta$-glucosidase activity were expressed in units per gram of dry substrate $\left(\mathrm{U} \mathrm{g}^{-1}\right)$.

Protease activity was quantified using azo casein $\left(5 \mathrm{~g} \mathrm{~L}^{-1}\right)$ as substrate, in sodium acetate $50 \mathrm{mmol} \mathrm{L}^{-1}, \mathrm{pH}$ 5. Briefly, $500 \mu \mathrm{L}$ of sample was mixed with the same volume of substrate solution and incubated at $37{ }^{\circ} \mathrm{C}$ for $40 \mathrm{~min}$. Afterwards, $1 \mathrm{~mL}$ of trichloroacetic acid $100 \mathrm{~g} \mathrm{~L}^{-1}$ was added to stop the reaction. Samples were centrifuged for $15 \mathrm{~min}$ at $600 \times \mathrm{g}$. Supernatant was recovered and after the addition of $1 \mathrm{~mL}$ of $5 \mathrm{~N}$ potassium hydroxide, the absorbance was read at $428 \mathrm{~nm}$. One unit of enzyme activity was defined as the amount of enzyme required to liberate $1 \mu \mathrm{mol}$ of azopeptides in $1 \mathrm{~min}$ at $37{ }^{\circ} \mathrm{C}$ and $\mathrm{pH}$. Values of protease activity was expressed in units per gram of dry substrate $\left(\mathrm{U} \mathrm{g}^{-1}\right)$.

\section{Statistical analysis}

Results were analysed by one-way analysis of variance (ANOVA) and post hoc Tukey's HSD (honestly significant difference) test to discriminate means $(P<0.05)$. Principal component analysis (PCA) was carried out using Statgraphics Plus 5.1 (Manusgistics, Inc., Rockville, MD, USA).

\section{RESULTS AND DISCUSSION}

\section{Characterization of oilseed cakes (OCs)}

OCs were physically and chemically characterized to assess their potential as substrate for SSF. Table 1 shows the initial composition of OCs.

OCs used in this study are natural sources of protein, corresponding to $40-50 \%$ of dry matter. Nitrogen $(\mathrm{N})$ and carbon (C) content are important parameters to take into account when assessing if a substrate is suitable to be applied in SSF. Nitrogen stimulates fungal conidiation, while $C$ represents the energy source to support microbial growth and metabolism. However, it was proven that the ratio of both contents $(\mathrm{C} / \mathrm{N})$ have higher significant effect in fungal growth and sporulation than $C$ sources alone. It is estimated that and optimal $\mathrm{C} / \mathrm{N}$ ratio is between 10 and 20, depending on the fungus strain. ${ }^{34}$ SFC, RSC and SBC are rich in $\mathrm{N}$ and presented a suitable $\mathrm{C} / \mathrm{N}$ ratio to be used as substrate in SSF studies without the need for external $\mathrm{N}$ supplementation. RSC and SBC C/N ratio were within the average values reported in the literature. ${ }^{20,24,29}$ SFC has a lower $\mathrm{C} / \mathrm{N}$ ratio, and this is attributable to a higher $\mathrm{N}$ content. It is known that soil composition and fertility, location, rainfall or temperature can influence the productivity and composition of crops. OCs obtained after mechanical press contain small amounts of residual oil or fat, referred to as lipids. The $O C$ treatments after oil extraction have a significant impact in the final OC composition. The amount of lipids in the present OCs accounted for approximately $2 \%$ of dry matter. Compared to the literature, differences on OC composition may be related with genotypic and phenotypic variations between cultivars, conditions in which the cultures were grown or even the use of total or dehulled oilseeds. ${ }^{4}$ Additionally, the method used to treat oilseeds during oil extraction and the use of extraction solvents can affect OC final composition. Also, other factors not inherent to oilseeds may affect final composition of OCs such as the expression of results to dry matter or moisture contents and the assays used. These factors may explain the low amount of total lipids observed in RSC in comparison to the literature. 
Table 1. Composition of oilseed cakes $\left(\mathrm{g} \mathrm{kg}^{-1}\right)$ and chemical composition of oilseed cakes reported in the literature

\begin{tabular}{|c|c|c|c|c|c|c|}
\hline \multirow[b]{2}{*}{ Parameter } & \multicolumn{2}{|r|}{ SFC } & \multicolumn{2}{|r|}{$\mathrm{RSC}$} & \multicolumn{2}{|c|}{ SBC } \\
\hline & Experimental & Literature & Experimental & Literature & Experimental & Literature \\
\hline Humidity & $98.23 \pm 0.91$ & $52.00-101.00^{20-22}$ & $152.64 \pm 3.00$ & $80.20-101.00^{20,22,23}$ & $132.13 \pm 1.56$ & $93.00-99.20^{23-25}$ \\
\hline Ash & $83.80 \pm 0.14$ & $52.60-75.00^{20-22,26}$ & $66.58 \pm 2.23$ & $43.00-70.0^{20,23,26-28}$ & $62.58 \pm 1.03$ & $58.30-74.80^{23-27}$ \\
\hline Protein & $401.99 \pm 5.88$ & $236.00-525.00^{20-22,26,27}$ & $398.29 \pm 20.86$ & $338.00-403.00^{20,22,26,28}$ & $504.11 \pm 14.26$ & $489.00-493.00^{23,26}$ \\
\hline Nitrogen & $69.50 \pm 5.05$ & $47.00^{20}$ & $76.44 \pm 7.02$ & $75.00^{20}$ & $91.07 \pm 3.02$ & $82.10^{24}$ \\
\hline Carbon & $466.62 \pm 2.34$ & $498.00^{20}$ & $505.88 \pm 8.06$ & $502.00^{20}$ & $473.49 \pm 4.94$ & $448.00^{24}$ \\
\hline $\mathrm{C} / \mathrm{N}$ ratio & 6.71 & $9.8-10.60^{20,29}$ & 6.62 & $6.69-8.40^{20,29}$ & 5.20 & $5.46^{24}$ \\
\hline Lipids & $23.44 \pm 3.91$ & $27.50-303.00^{20,21}$ & $20.42 \pm 2.80$ & $118.00-167.00^{20,28}$ & $17.16 \pm 1.62$ & $21.00^{25}$ \\
\hline Water Holding capacity & $359 \pm 35$ & & $193 \pm 5$ & & $285 \pm 30$ & $500^{30}$ \\
\hline $\mathrm{pH}^{\mathrm{a}}$ & 5.33 & & 5.50 & & 5.22 & \\
\hline Klason lignin & $82.54 \pm 0.51$ & $77.20-133.00^{20,31,32}$ & $77.42 \pm 16.97$ & $64.00-90.00^{20,27,32}$ & $22.01 \pm 1.35$ & $10.00-28.00^{24,27}$ \\
\hline Cellulose & $142.79 \pm 2.43$ & $123.00-251.00^{20,31,32}$ & $154.69 \pm 16.35$ & $59.00-81.80^{20,32}$ & $161.54 \pm 2.71$ & $215.80^{24}$ \\
\hline Hemicellulose & $111.43 \pm 6.68$ & $44.20-154.00^{20,31}$ & $136.27 \pm 14.33$ & $20.40^{20,32}$ & $155.47 \pm 6.53$ & $525.10^{24}$ \\
\hline NDF & 336.76 & $216.00-453.00^{27,33}$ & 368.38 & $200.00-299.00^{23,27}$ & 339.02 & $111.00-158.90^{23,27}$ \\
\hline ADF & 225.33 & $145.00-372.00^{27,33}$ & 232.11 & $141.00^{27}$ & 183.55 & $78^{27}$ \\
\hline Soluble protein ${ }^{b}$ & $7.92 \pm 0.39$ & & $11.89 \pm 0.66$ & & $8.41 \pm 0.18$ & \\
\hline Free sugars $^{\mathrm{b}}$ & $7.68 \pm 0.06$ & & $9.70 \pm 0.48$ & & $7.27 \pm 0.32$ & \\
\hline Total phenolic content $^{\mathrm{b}}$ & $11.68 \pm 0.17$ & & $4.77 \pm 0.16$ & & $3.10 \pm 0.16$ & \\
\hline
\end{tabular}

Cellulose and hemicellulose content were similar in the three OCs while, SFC and RSC presented a higher concentration of lignin. Cellulose and hemicellulose fractions can act as inductors for the production of lignocellulolytic enzymes such as cellulases and xylanases, respectively. ${ }^{7}$ These enzymes are responsible for the degradation of cellulose and hemicellulose, respectively, increasing OC digestibility in livestock. Neutral detergent fibre (NDF) and acid detergent fibre (ADF) are good indicators of feed quality once they are correlated with digestibility by livestock animals. They are good indicators of dietary energy and intake, with focus for ruminant rations. All three OCs presented similar values of NDF and ADF and were within the range of the values reported by the literature with the exception of SBC that present slightly higher values. All the OCs retained water that is critical in SSF. WHC represents the water absorbed by the substrate fibres under limiting conditions and that can be used by the fungi to support its growth. Substrates used in SSF process usually have low water content. However, substrates with high WHC are normally selected for being used in SSF once the moisture can be easily modified according to the process needs. Ngoc et al. ${ }^{30}$ reported values of WHC for different fibre-rich plant sources and agro-industry by-products ranging from 2.5 and $8.0\left(\mathrm{~kg} \mathrm{~kg}^{-1}\right.$ of dry matter). WHC is related with the content of lignocellulosic fractions. SBC had a lower WHC compared to the values reported in the literature and this may be explained by the low concentrations of hemicellulose and cellulose. All cakes in this study had a similar $\mathrm{pH}$ value, around 5 , which is found to be within the optimal range for filamentous fungal growth (3.8-6.0). The three OCs contain small fractions of free extractable compounds such as phenolics, sugars and proteins. In the present work, these fractions were obtained through an aqueous extraction.

\section{Antioxidant potential of oilseed cakes (OCs)}

Phenolic compounds are amongst the secondary metabolites produced by plants. Figure $1(\mathrm{~A})$ represents the concentrations of TPC, obtained after aqueous extraction, of each OC. SFC is the by-product with higher content of TPC. Its concentration is 1.94-fold higher than RSC and approximately 2.73-fold higher than SBC. It is known that OCs contain high fractions of phenolic compounds. However, the presence of some of these compounds can hinder their use as animal feed as they can negatively affect protein digestibility from $\mathrm{OC}$ due to complex protein-phenolic compound interactions. However, other phenolics may present relevant bioactivities, since they may provide health benefits due to antioxidant properties, induction or inhibition of enzymes and gene expression. ${ }^{35}$ Figure $1(\mathrm{~B}-\mathrm{E})$ depicts the results of antioxidant analysis of sample extracts. Regarding capacity to scavenge the DPPH radical (Fig. 1(B)), the maximum value was obtained in SFC extract, that was two- and six-fold higher than the values obtained with RSC and SBC, respectively. The scavenging of free radicals of each extract is in agreement with the concentration of TPC. Figure $1(\mathrm{C})$ represent the ability to chelate iron of the extracts. This metal catalytic oxidation process resulted in a decrease of hydroxyl radical generation through Fenton reactions. Aqueous extracts of SFC had the highest capacity to chelate iron, and the values obtained with SFC and SBC did not present statistically significant differences $(P<0.05)$. The low capacity to chelate iron of RSC extracts may be explained by a different nature of phenolics present in this extract. Iron is an element that can undergo cyclic oxidation and reduction and is involved in the Fenton reaction leading to the production of ROS that are capable of oxidizing a range of organic substrates.

Superoxide anion is formed within the mitochondria, peroxisomes and endoplasmic reticulum. ${ }^{36}$ This anion is one of the three primary species of ROS, alongside hydrogen peroxide and 
(A)

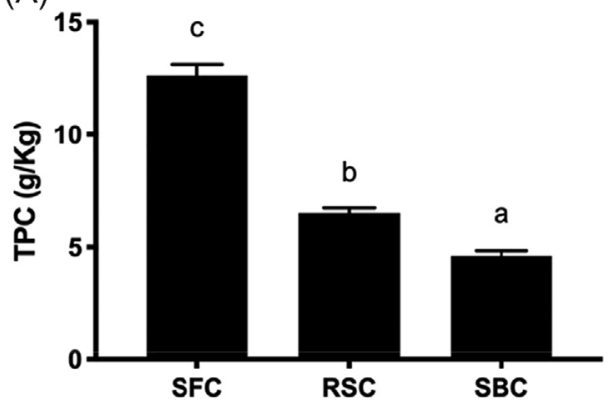

(C)
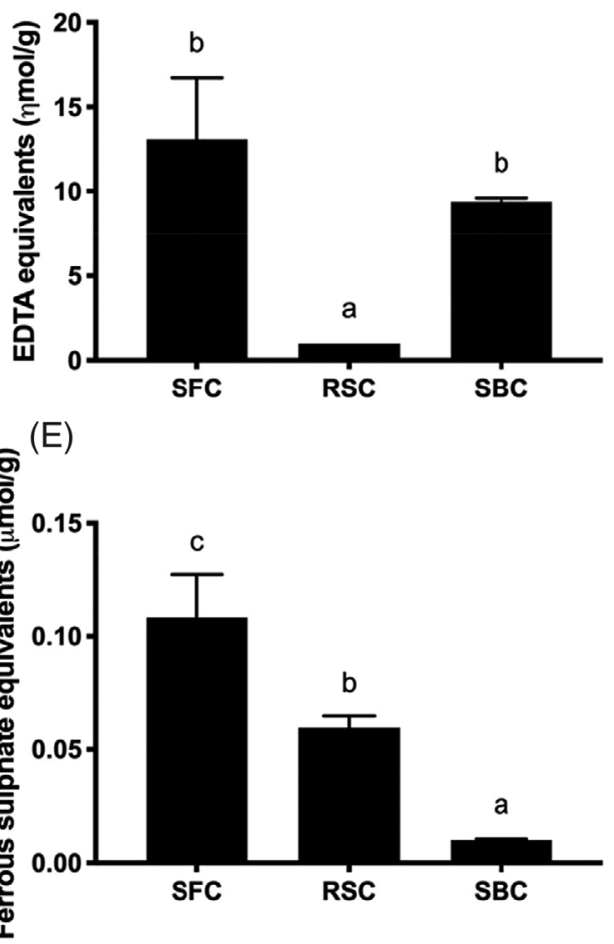

(B)

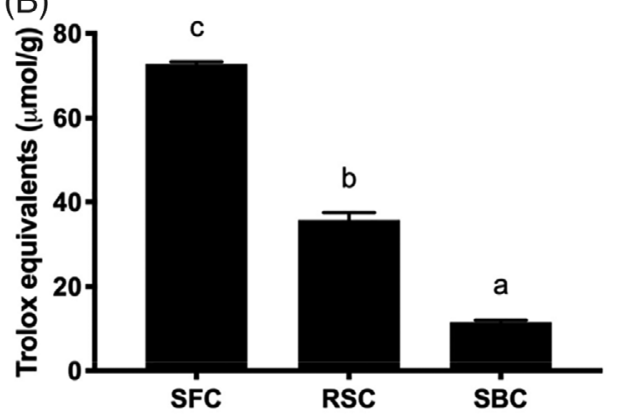

(D)

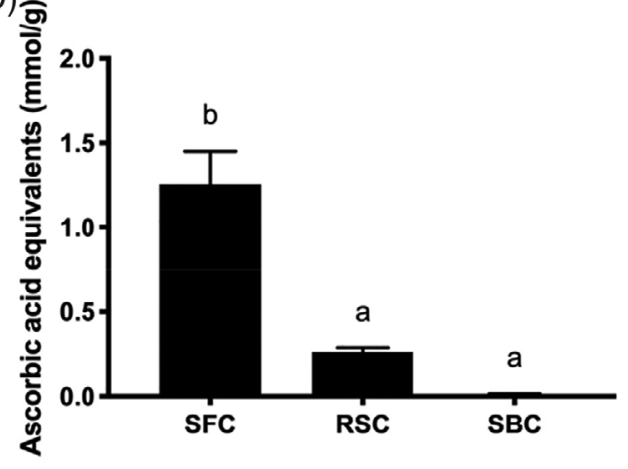

Figure 1. Total phenolic content (TPC) and antioxidant potential of aqueous extracts of non-fermented oilseed cakes. (A) TPC; (B) DPPH radical scavenging activity; (C) iron chelation ability; (D) superoxide radical scavenging activity; (E) reducing ability. Results represent the average of two independent experiments and error bars represent standard deviation. Bars with equal letters are not statistically significant different (Tukey test; $P<0.05$ ).

hydroxyl radical. They can react with organic substrates leading to the production of intermediate species able to produce more ROS. ${ }^{37}$ From Fig. 1(D) is possible to observe that SFC extracts presented the highest superoxide anion scavenging capacity among the three OC extracts. SFC scavenging capacity was 4.8-fold higher than RSC and SBC, with no statistically significant differences $(P<0.05)$ between the results among these two OCs.

Figure $1(E)$ show the results of FRAP assay of OC extracts. This method is based on the antioxidant strength in reducing the ferrous tripyridyltriazine (Fe"ll-TPTZ) complex to its stable form (Fe-TPTZ). Extracts that exhibit antioxidant capacity in this assay,

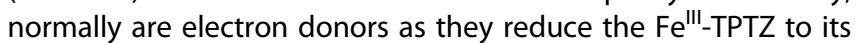
stable form interrupting the oxidation chain. ${ }^{38}$ Results follow a similar trend as the ones obtained through the DPPH assay. Statistically significant differences $(P<0.05)$ were observed between the three extracts. SFC extracts have the highest reducing power, that is 1.86 -fold higher than the obtained value in RSC. SBC extract showed the lowest reducing power being 11 -fold lower than SFC.
In general, it may be concluded that SFC is the OC with more potential for antioxidant compounds extraction by an ecofriendly solvent (water). Extracts of SFC are rich in antioxidant phenolic compounds. Mohdaly and Ramadan ${ }^{39}$ reported DPPH scavenging potentials between $46 \%$ and $71 \%$ of different Brassica carinata genotypes. From the 20 B. carinata genotypes studied, only two achieved a scavenging potential near SFC. Compared to agro-industrial wastes from winery, brewery and olive oil industry namely vine shoot trimmings, exhausted grape marc, grape stalks, crude and exhausted olive pomace and brewers spent grain, SFC antioxidant potential is considerably high, achieving scavenging potential values between 1.44 and 14.4-fold higher than the referred residues. ${ }^{10}$

\section{Production of enzymes by solid-state fermentation (SSF)}

OCs were used as substrate in SSF with three fungi species. Figure 2 shows the activity of cellulases, xylanases, $\beta$-glucosidases and proteases obtained after SSF. Cellulases maximum activity, 
was achieved with $A$. niger, using SBC as substrate (Fig. 2(A)). Aspergillus niger was in general the best producer of cellulases in the three OCs at the SSF conditions used, however no statistically significant differences $(P<0.05)$ were found between cellulases produced by $A$. niger and $A$. ibericus using SFC as substrate. Maximum xylanases activity was obtained using RSC as substrate fermented by $A$. niger and this enzyme production was $66 \%, 85 \%$ and $69 \%$ (SFC, RSC and SBC, respectively) higher than the obtained with $A$. ibericus, that was the second largest producer (Fig. 2(B)).

However, maximum activity of $\beta$-glucosidases was achieved with $R$. oryzae and $A$. ibericus using RSC as substrate, being similar $(P<0.05)$ amongst them (Fig. 2(C)). Regarding SFC and SBC, no statistically significant differences $(P<0.05)$ were observed between enzymes produced by each fungus.

The use of SFC and canola (a cultivar of rapeseed) for the production of cellulases and xylanases, using different Aspergillus species, was evaluated by de Castro et al. ${ }^{29}$ Maximum enzyme activity for these substrates was achieved using A. awamori IOC3915. They reported activity values of 9.7 and $6.1 \mathrm{U} \mathrm{g}^{-1}$ for cellulases and 413.5 and $571.4 \mathrm{U} \mathrm{g}^{-1}$ for xylanases activity, respectively for each substrate. Aspergillus niger IOC-4003 produced cellulases activity of 1.1 and $0.2 \mathrm{U} \mathrm{g}^{-1}$ and xylanases activity of 40.6 and $13.7 \mathrm{U} \mathrm{g}^{-1}$ using SFC and canola cake as substrate, respectively. The use of soybean meal as substrate for a multienzyme production was evaluated by Vitcosque et al. ${ }^{40}$ They observed a maximum xylanases production of $47.7 \mathrm{U} \mathrm{g}^{-1}$, using $A$. niger. Despite this, the production of $\beta$-glucosidases using $O C$ as substrate for
SSF has not been yet extensively explored, but studies using other lignocellulosic materials to produce this enzyme have been performed. Leite et al., ${ }^{10}$ reported a maximum activity of $93.66 \mathrm{U} \mathrm{g}^{-1}$ of $\beta$-glucosidases for $A$. niger CECT2088 using brewer's spent grain as substrate. Filipe et al., ${ }^{41}$ optimized the production of $\beta$-glucosidases using olive mills and winery wastes as SSF substrate, achieving maximum enzyme activity of 25.5 and $17.9 \mathrm{U} \mathrm{g}^{-1}$ by $A$. ibericus MUM 03.49 and A. niger CECT 2915, respectively. Ezeilo et al., ${ }^{42}$ reported that $R$. oryzae presented maximum $\beta$-glucosidases activity of $145.47 \mathrm{U} \mathrm{g}^{-1}$ after optimization of SSF parameters, using raw oil palm frond leaves as substrate.

Apart from lignocellulolytic enzymes produced by filamentous fungi during SSF, several other enzymes can be produced using this process. Proteases are among the wide spectrum of enzymes that can be produced by SSF. ${ }^{6}$

Maximum protease activity was achieved with SFC and A. niger however, no statistically significant differences $(P<0.05)$ were found between those values and the ones obtained with the other fungi in SFC (Fig. 2(D)). SSF of RSC and SBC led to lower production of protease with all the fungi than the obtained with SFC but $A$. niger was the best producer $(P<0.05)$ in these OCs. Aspergillus niger is one of the most important sources of fungal proteases, its genome sequencing by $\mathrm{Pel}$ et $a l^{43}$ revealed 198 proteins involved in proteolytic degradation process. de Castro et al. ${ }^{29}$ reported proteases production of 0.8 and $0.5 \mathrm{U} \mathrm{g}^{-1}$ using SFC and canola cake as substrates for SSF. In the same work it was reported maximum proteases production of 9.9 and $12.6 \mathrm{U} \mathrm{g}^{-1}$, using SFC and canola cake as substrate for SSF when

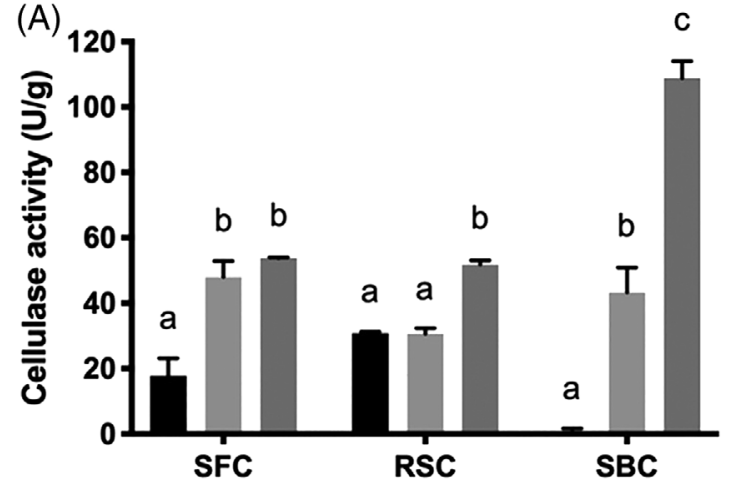

(C)

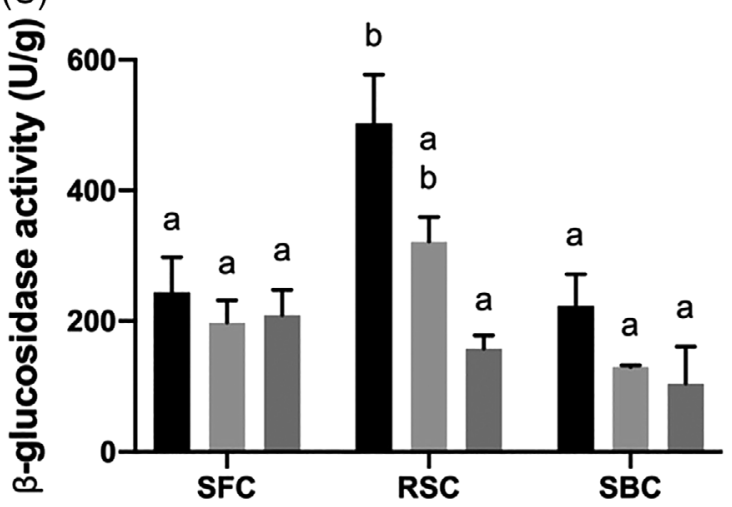

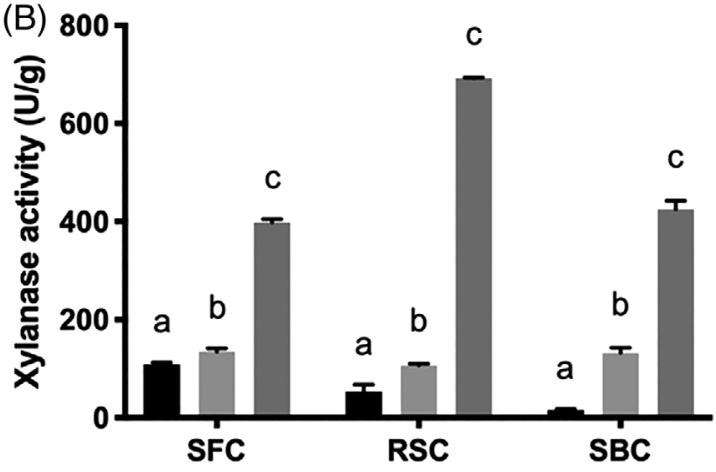

(D)

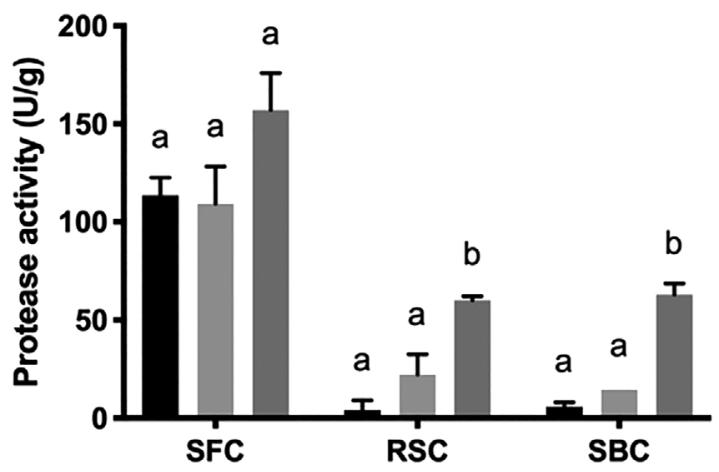

A. ibericus A. niger

Figure 2. Cellulases (A), xylanases (B), $\beta$-glucosidases (C) and proteases (D) production during solid-state fermentation (SSF). Results represent the average of two independent experiments and error bars represent standard deviation. Bars with equal letters are not statistically significant different (Tukey test; $P<0.05$ ). Statistical analysis is relative to each oilseed cake. 
fermented with A. awamori IOC-3915 and A. sulphureus, respectively. Mukhtar ${ }^{44}$ achieved maximum protease activity of $5.2,3.3$ and $4.8 \mathrm{U} \mathrm{g}^{-1}$ of dry substrate, for sunflower meal, rapeseed meal and soybean meal, respectively, using $A$. niger $\mathrm{IGH}_{9}$.

Overall, $A$. niger was the fungus that produced higher activities of enzymes mainly using SFC and RSC as substrate. However, $\mathrm{SBC}$ favoured the production of cellulase.

Enzymatic activity values achieved during this work easily outpace the ones reported by other authors. Cellulase maximum activity of $109 \mathrm{U} \mathrm{g}^{-1}$ exceeded the maximum production of $84.2 \mathrm{U} \mathrm{g}^{-1}$ reported by Filipe et al. ${ }^{41}$ by 1.3 -fold. Regarding xylanase, an increased difference of $100 \mathrm{U} \mathrm{g}^{-1}$ was obtained comparatively to the maximum of $598 \mathrm{U} \mathrm{g}^{-1}$ reported by de Castro et al. ${ }^{29}$ In relation to $\beta$-glucosidase production an increase of approximately $71 \%$ was observed from the maximum of $145 \mathrm{U} \mathrm{g}^{-1}$ reported by Ezeilo et al. $^{42}$ and the maximum obtained in this work of nearly $503 \mathrm{U} \mathrm{g}^{-1}$. Additionally, protease maximum production of $157 \mathrm{U} \mathrm{g}^{-1}$ was around 30-fold higher than the maximum of $5.2 \mathrm{U} \mathrm{g}^{-1}$, reported by Mukhtar. ${ }^{44}$

\section{Antioxidant capacity of extracts of fermented oil cakes}

TPC and antioxidant potential of aqueous extracts of fermented OCs were evaluated and compared with unfermented sterilized OCs. According to the results in Fig. 3(A), SSF had a positive effect, comparing to controls, on the increment of TPC concentration in the extracts obtained with all the fungi in RSC and SBC, and with $R$. oryzae in SFC, where the action of the other fungi did not affect the TPC liberation. For SSF with $R$. oryzae the increase of TPC in the extracts compared to controls was approximately of 2.6-fold in SFC, 5.6-fold in RSC and 10-fold in SBC. These results indicate the importance of SSF for TPC extraction of OC that are more resistant to direct extraction process with eco-friendly solvents.

TPC increase during SSF may be related with the action of lignocellulolytic enzymes. Insoluble phenolic compounds can be found connected to structures of the vegetable cell wall such as arabinose or galactose residues of hemicellulose components and also to lignin, which is a network of phenolic compounds. ${ }^{45}$ Filamentous fungi possess two extracellular enzymatic systems, an hydrolytic one that produces hydrolases, able to degrade polysaccharides and an oxidative system, responsible for the degradation of lignin and opening of phenyl rings, increasing free phenolics. ${ }^{46}$ The decomposition of linkages between lignin, cellulose or hemicellulose increases the release of phenolic compounds.

Highest concentration of TPC was observed in fermentation performed with $R$. oryzae which, also reported the maximum $\beta$-glucosidase activity. Sheih et al. ${ }^{47}$ observed that $\beta$-glucosidase, alongside $\alpha$-amylase were responsible for the mobilization of phenolics during $A$. niger M46 fermentation.

Figure 3(B-E) show the results obtained of four different antioxidant assays performed with OC fermented extracts to assess their antioxidant potential. Regarding the ability to scavenge free radicals (Fig. 3(B)), maximum antioxidant potential was obtained in aqueous extracts of RSC fermented with $A$. niger, that was the fungi with which highest values of antioxidant potential were achieved in fermentations performed with all OCs. Aspergillus niger was able to increase antioxidant potential of extracts in approximately 2-, 4.6- and 14.3-fold for SFC, RSC and SBC, respectively. Surprisingly, $R$. oryzae fermented extracts achieved lower values of antioxidant potential than $A$. niger. These results indicate that the phenolic compounds that are liberated by the action of these fungi species are different and may be related with the action of enzymes most produced by each species, as it was found in this work. In fact, the direct correlation of TPC and antioxidant capacity may be difficult to establish as found by Terpinc et al. ${ }^{48}$ that studied the correlation between TPC and antioxidant potential of different oil cake extracts. They observed a negative correlation between these two parameters. Additionally, the authors suggested that samples with similar concentrations of TPC vary significantly in their antioxidant activity. The same was observed in this work between fermented extracts of $A$. ibericus and $A$. niger. This fact may be explained by the synergistic and antagonistic interactions between the antioxidants. The action of lignocellulolytic enzymes such as cellulases and xylanases can also lead to antioxidant potential differences once the hydrolysis of some phenolic conjugates, present in the lignocellulosic matrix of plant cell walls, can release free phenolic compounds and low molecular weight molecules with higher antioxidant potential.

The highest antioxidant potential of extracts from fermented OC with A. niger was also observed in the results of the ability to chelate iron (Fig. 3(C)) where the maximum capacity was observed in fermented extracts of SBC. Generally, SSF increased capacity to chelate iron of the extracts compared to the control, with the exception of SFC when fermented with A. ibericus.

With respect to the superoxide scavenging potential (Fig. 3(D)), fermented extracts showed a significant increase of antioxidant potential regarding the controls. Maximum scavenging potential was observed in A. niger extracts with SFC. Aspergillus niger was responsible for the highest increases in extracts scavenging potential in SFC and SBC. A 3.22-fold increase was observed in SFC extracts while in SBC the increment was near 233-fold. Concerning RSC, $A$. ibericus led to a 21.7-fold increase of scavenging potential.

As shown in Fig. 3(E), SFC fermented extracts reducing power decreased around $57 \%$ when compared to control. SFC presented a relatively higher reducing power when compared to RSC and SBC. In this case, the action of the microorganisms may lead to a decrease of electron donor species due to their consumption or lead to the aggregation of species causing a decrease in the reducing power capacity. However, regarding RSC and SBC fermented extracts a clear increase of reducing power ability was observed. Maximum reducing power was observed in fermented extracts of RSC with $R$. oryzae and A. niger, showing no statistically significant differences $(P<0.05)$. This is a 20 -fold increase while on SBC extracts a 4.75 -fold increase was observed.

SSF has been widely used to improve the nutritional properties of agricultural products and to obtain bioactive compounds. In this work, SSF was able to increase the antioxidant capacity of extracts as previously described by other authors for other substrates. Zhai et al. ${ }^{49}$ reported an increase of $89 \%, 66.1 \%, 86.5 \%$ and $72.9 \%$ regarding DPPH radical scavenging ability, ferrous ion chelating ability, superoxide anion radical scavenging ability and reducing power, respectively, of ethanolic extracts of corn fermented with Agaricus brasiliensis SH26. The same author reported an increase of $99.3 \%, 87.4 \%, 85 \%$ and $91.4 \%$ for the same four antioxidant indexes of ethanolic extracts of corn fermented with Agaricus bisporus 2796. Xu et al. ${ }^{50}$ tested the effect of SSF on the antioxidant properties of ten cereal grains. This author reported an increase of antioxidant potential of all cereal grains regarding their ability to scavenge the DPPH radical, reducing power ability, ferrous ion chelating activity and superoxide anion radical scavenging capacity of ethanolic extracts. Kang et al. ${ }^{51}$ reported the increase of buckwheat antioxidant potential regarding the DPPH and superoxide scavenging abilities, reducing power and ferrous 
(A)

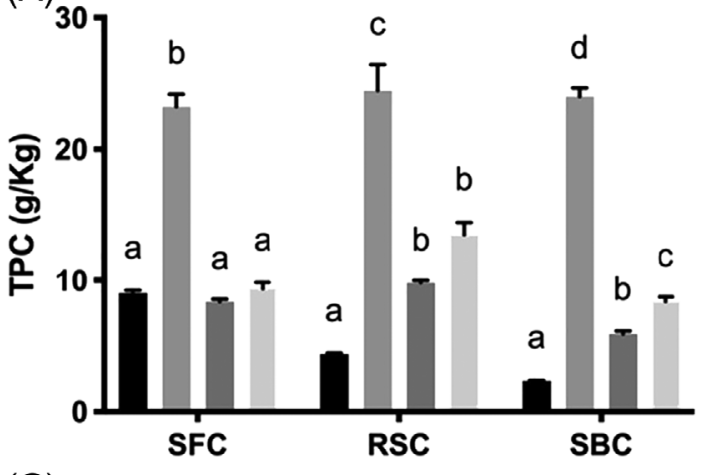

(C)

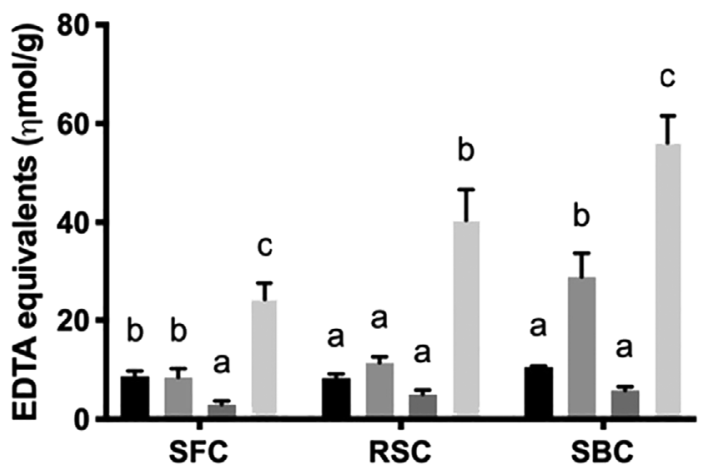

(E)

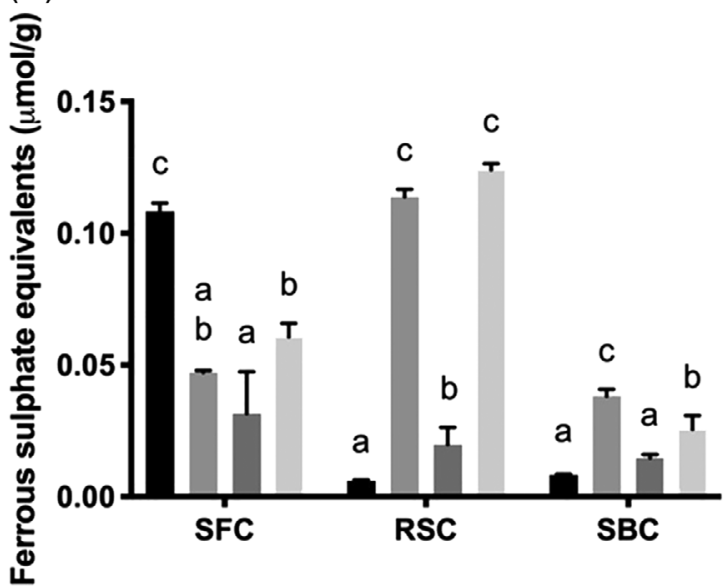

(B)

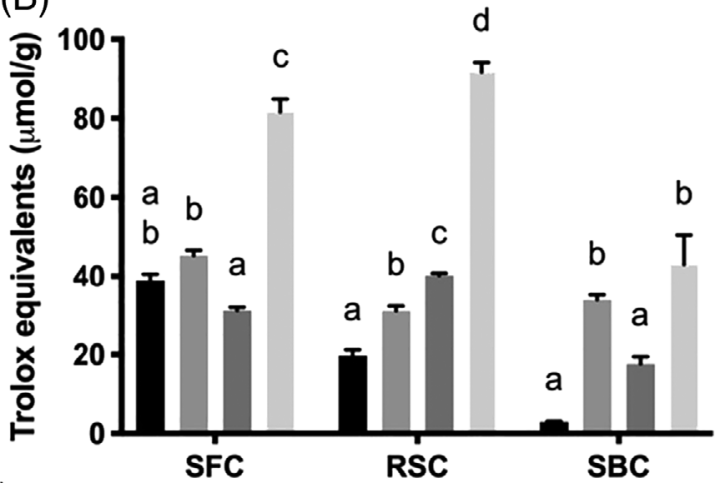

(D)

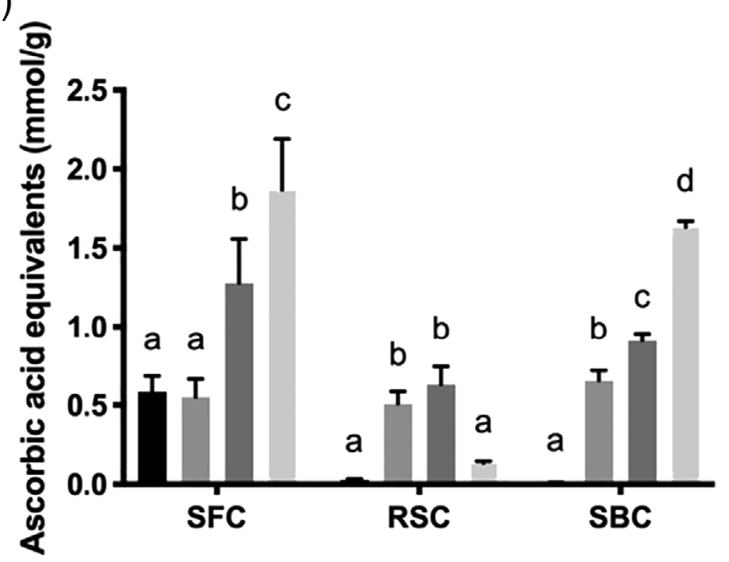

Figure 3. Total phenolic content (TPC) and antioxidant potential of aqueous extracts of controls (oilseed cake sterilized) and fermented oilseed cakes. (A) TPC; (B) DPPH radical scavenging activity; (C) iron chelation ability; (D) superoxide radical scavenging activity; (E) reducing ability. Results represent the average of two independent experiments and error bars represent standard deviation. Bars with equal letters are not statistically significant different (Tukey test; $P<0.05$ ). Statistical analysis is relative to each oilseed cake.

ion chelating activity after SSF with Agaricus blazei and Agaricus bisporus.

\section{Nutritional parameters of fermented oilseed cakes (OCs)}

Relevant physico-chemical parameters to assess nutritional quality of fermented OCs were evaluated on fermented and extracted OCs. Figure 4(A) shows that in SSF experiments using $A$. niger, no loss of crude protein was found in the fermented OC.

However, with $R$. oryzae and $A$. ibericus, there was a decrease in crude protein during the SSF process. SSF has been used over the past decades to improve the nutritional value of agricultural wastes, namely protein content. In a previous work, SSF of brewer's spent grain, exhausted olive pomace, exhausted grape pomace and vine-shoots trimming was successfully applied for the production of single cell protein, using different Aspergillus strains. ${ }^{52}$ Canedo et al. ${ }^{53}$ was able to increase crude protein of brewer's spent grain by two-fold, using the genus Rhizopus in SSF. However, in this study, the decrease in crude protein content using $R$. oryzae and $A$. ibericus could indicate that these fungi can use the available $\mathrm{N}$ to support their growth and differentiation, as there was not any external $\mathrm{N}$ supplementation.

During SSF, lignocellulosic fractions are affected by the activity of microorganisms. Filamentous fungi degrade the lignocellulosic matrix into small soluble sugars that can be further consumed by 

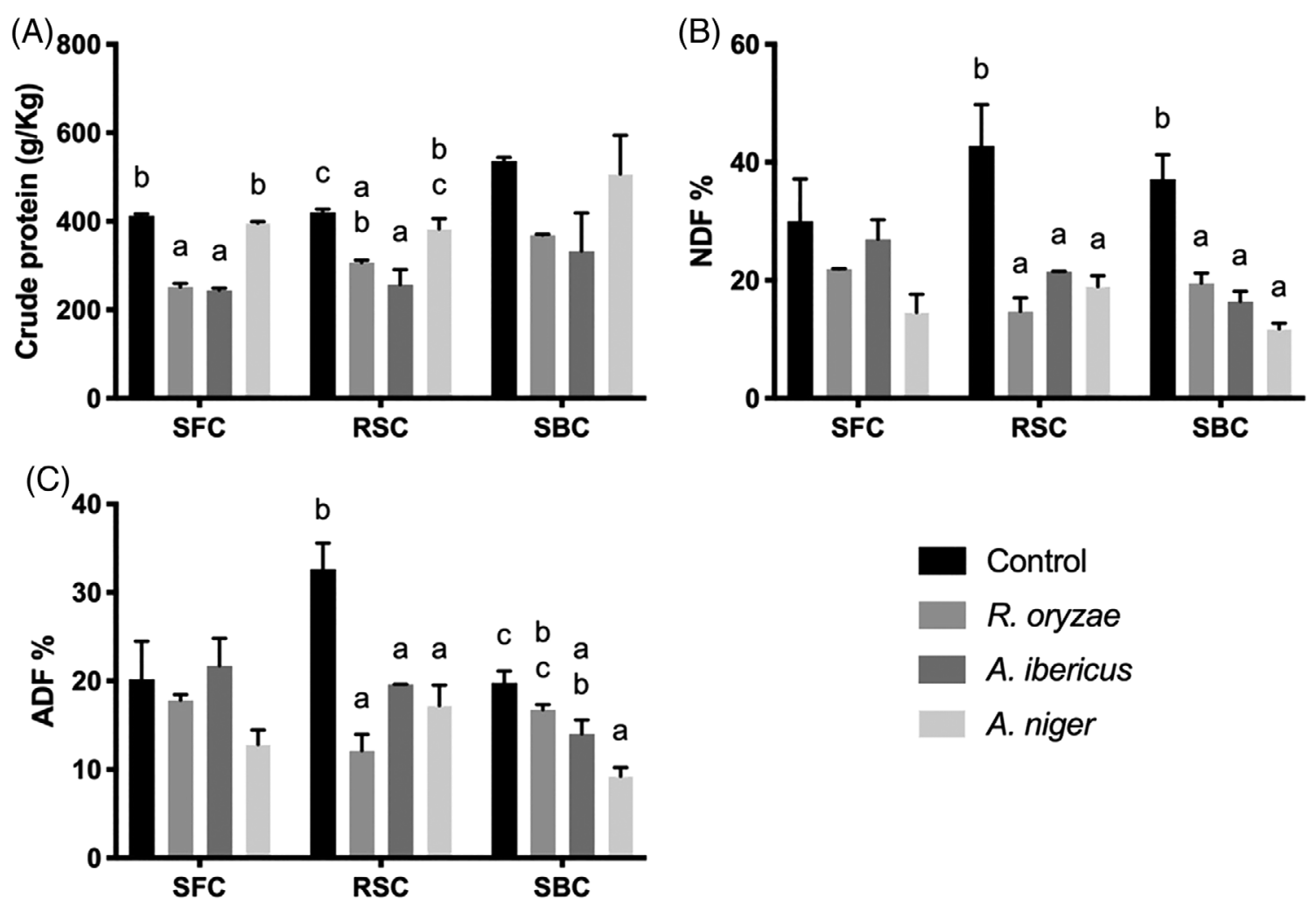

Figure 4. Crude protein (A), neutral detergent fibre (NDF) (B) and acid detergent fibre (ADF) (C) of controls (oilseed cake sterilized) and fermented oilseed cakes. Results represent the average of two independent experiments and error bars represent standard deviation. Bars with equal letters are not statistically significant different (Tukey test; $P<0.05$ ). Statistical analysis is relative to each oilseed cake.

the microorganisms. Compositional changes regarding dietary fibres are quite important during bioconversion studies, such as SSF, once these fractions can affect OC digestibility by animals. NDF and ADF fractions were thus evaluated during this work (Fig. $4(B, C)$, respectively). Decrease of these fractions was observed in all fermented OCs with the exception of SFC for which NDF and ADF content values of fermented OCs were not statistically significant different $(P<0.05)$ from the non-fermented ones. Decreases in cell wall components of $53 \%, 67 \%$ and $69 \%$ were observed in SFC, RSC and SBC, respectively, regarding NDF composition. Additionally, ADF decreases of $37 \%, 63 \%$ and $53 \%$ were observed for SFC, RSC and SBC, respectively. These results may be explained by the action of fungal enzymes produced during SSF that breakdown lignocellulosic bounds between lignin, cellulose and more particularly with hemicellulose. The fibre reduction is an important result of nutritional upgrade of OC for their application as animal feed. The use of filamentous fungi to increase the nutritional value of OCs to be used in animal feed does not entail any obstacle and is a viable technique due to the nature of the species used. The fungi used during this study

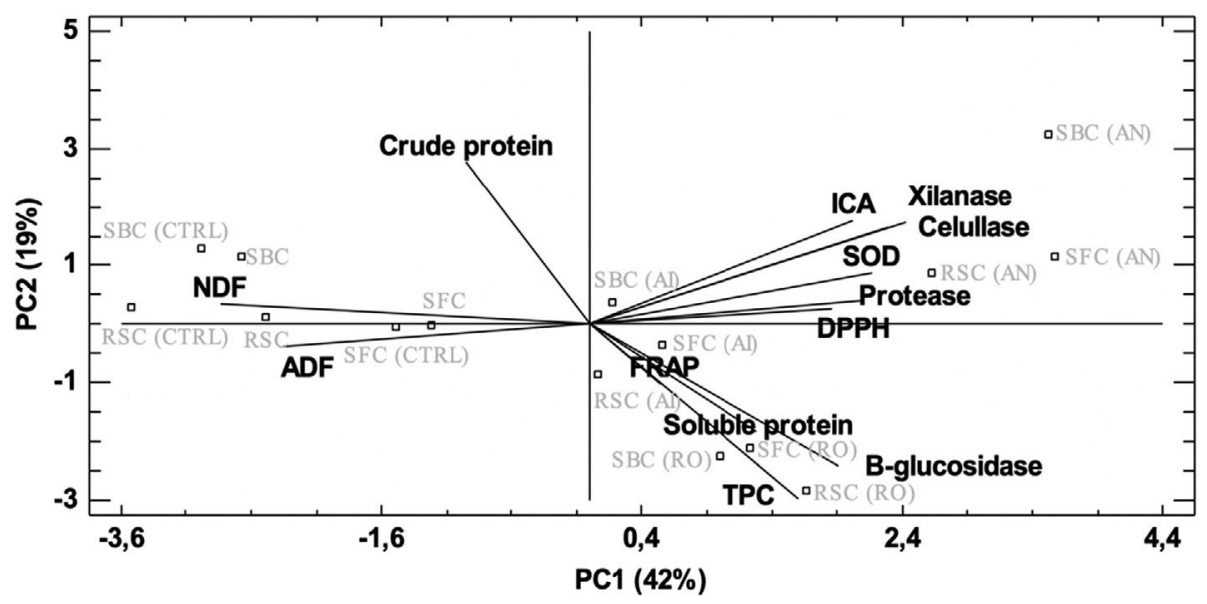

Figure 5. Principal component analysis. Biplot representation of variables and soild-state fermentation (SSF) experiments performed. CTRL, control; RO, Rhyzopus oryzae; Al, Aspergillus ibericus; AN, Aspergillus niger. 
are recognized as GRAS (generally recognized as safe) by the US Food and Drug Administration (FDA). Aspergillus niger is one of the most used species in SSF. Aspergillus ibericus does not produce any relevant toxins and $R$. oryzae has been used in SSF studies using agro-food residues for the production of extracellular enzymes. ${ }^{6,52,54}$

\section{Principal component analysis}

A PCA was performed in order to assess the relationship between substrates, fungi, TPC, antioxidant capacity, enzymes produced, crude and soluble protein and lignocellulosic fractions (NDF and ADF). PCA allowed to obtain a reduced number of linear combinations of the 13 variables studied to explain data variability. With this analysis, four main components were identified and explain $84.59 \%$ of the variability of original data. The first two principal components, PC1 and PC2, are shown in Fig. 5, and they accounted for $61 \%$ of the variability ( $42 \%$ and $19 \%$, respectively). PC1 was positively characterized by high enzymatic activity (xylanase, cellulase, protease and $\beta$-glucosidase), TPC and antioxidant potential. However, PC1 was negatively correlated with NDF and ADF. As seen in Fig. 5, substrates with higher concentrations of lignocellulosic fractions lead to a higher production of xylanase and cellulase. The deconstruction of lignocellulosic materials due to enzymatic activity is also positively correlated with an increased antioxidant potential.

For PC2, crude protein and NDF were correlated positively while TPC, $\beta$-glucosidase and soluble protein were correlated negatively. It is possible to observe the effect of crude protein in protein solubilization and a relationship between $\beta$-glucosidase activity and increase of TPC. Despite having a similar composition, PCA grouped OCs and controls with respect to their fibre content according to the following order: SBC > RSC > SFC. Additionally, with this analysis it was possible to correlate fungus strain with their main bioactivity. Rhyzopus oryzae was characterized by a high production of $\beta$-glucosidase and TPC alongside protein solubilization. Aspergillus ibericus was slightly correlated with antioxidant potential and enzymes production. Aspergillus niger was highly correlated with enzymes production (cellulase, xylanase and protease) and antioxidant potential (ICA, superoxide dismutase, DPPH).

Degradation of lignocellulosic fractions from OCs by fungi extracellular enzymes was demonstrated and this can favour nutrient digestibility of OCs by farmed animals. Also, this degradation led to the release of phenolic compounds with potential antioxidant capacity. This study showed the potential of OCs to be used in SSF to obtain new fermented and upgraded by-products as well as enzymatic rich extracts with antioxidant capacity, that also have potential to be applied in the food and feed industry. The use of biotechnological process for valorization of by-products without generating any additional waste is the key to sustainable development.

\section{ACKNOWLEDGEMENTS}

The authors thank the Portuguese Foundation for Science and Technology (FCT) under the scope of the strategic funding of UIDB/BIO/04469/2020 and UIDB/04033/2020 units.

Daniel Sousa was supported by the FCT (PD/BD/135328/2017), under the Doctoral Programme 'Agricultural Production Chains - from fork to farm' (PD/00122/2012).

José Manuel Salgado was supported by grant CEB/N2020 INV/01/2016 from Project 'BIOTECNORTE - Underpinning
Biotechnology to foster the north of Portugal bioeconomy' (NORTE-01-0145-FEDER-000004).

\section{CONFLICT OF INTEREST}

The authors confirm that they have no conflicts of interest with respect to the work described in this article.

\section{REFERENCES}

1 FAO, The Future of Food and Agriculture - Alternative Pathways to 2050. FAO, Rome (2018).

2 Gupta SK, Technological Innovations in Major World Oil Crops, Volume 1: Breeding. Springer Science \& Business Media, Berlin (2011).

3 USDA, Oilseeds: World Markets and Trade. US Department of Agriculture, Washington, DC (2021).

4 Arrutia F, Binner E, Williams P and Waldron KW, Oilseeds beyond oil: press cakes and meals supplying global protein requirements. Trends Food Sci Technol 88-102:100 (2020).

5 Greiling AM, Reiter R and Rodehutscord M, Utilization of unprocessed and fibre-reduced oilseed cakes of rapeseed and sunflower seed in rainbow trout (Oncorhynchus mykiss W.) nutrition-evaluation of apparent digestibility and growth performance. Aquacult Nutr 24: 1133-1143 (2018).

6 Singhania RR, Patel AK, Soccol CR and Pandey A, Recent advances in solid-state fermentation. Biochem Eng J 44:13-18 (2009).

7 Leite P, Salgado JM, Venâncio A, Domínguez JM and Belo I, Ultrasounds pretreatment of olive pomace to improve xylanase and cellulase production by solid-state fermentation. Bioresour Technol 737-46: 214 (2016).

8 Fazary AE, Hamad HA, Lee JC, Koskei T, Lee C-K and Ju Y-H, Expression of feruloyl esterase from Aspergillus awamori in Escherichia coli: characterization and crystal studies of the recombinant enzyme. Int J Biol Macromol 46:440-444 (2010).

9 Cocero MJ, Cabeza A, Abad N, Adamovic T, Vaquerizo L, Martinez CM et al., Understanding biomass fractionation in subcritical \& supercritical water. J Supercrit Fluids 133:550-565 (2018).

10 Leite $\mathrm{P}$, Silva C, Salgado JM and Belo I, Simultaneous production of lignocellulolytic enzymes and extraction of antioxidant compounds by solid-state fermentation of agro-industrial wastes. Ind Crops Prod 137:315-322 (2019).

11 Ancuța $P$ and Sonia A, Oil press-cakes and meals valorization through circular economy approaches: a review. Appl Sci 10:7432 (2020).

12 Faustino M, Veiga M, Sousa P, Costa EM, Silva S and Pintado M, Agrofood byproducts as a new source of natural food additives. Molecules 24:1056 (2019).

13 Mahato N, Sharma K, Sinha M and Cho MH, Citrus waste derived nutra -/pharmaceuticals for health benefits: current trends and future perspectives. J Funct Foods 40:307-316 (2018).

14 Fierascu RC, Fierascu I, Avramescu SM and Sieniawska E, Recovery of natural antioxidants from agro-industrial side streams through advanced extraction techniques. Molecules 24:4212 (2019).

15 Zhu HL, Hu LL, Hou YQ, Zhang J and Ding BY, The effects of enzyme supplementation on performance and digestive parameters of broilers fed corn-soybean diets. Poult Sci 93:1704-1712 (2014).

16 Dulf FV, Vodnar DC, Dulf E-H and Toşa MI, Total phenolic contents, antioxidant activities, and lipid fractions from berry pomaces obtained by solid-state fermentation of two Sambucus species with Aspergillus niger. J Agric Food Chem 63:3489-3500 (2015). https://doi.org/ 10.1021/acs.jafc.5b00520.

17 Oliveira Al, Pinho C, Fonte P, Sarmento B and Dias ACP, Development, characterization, antioxidant and hepatoprotective properties of poly( $\mathcal{E}$-caprolactone) nanoparticles loaded with a neuroprotective fraction of Hypericum perforatum. Int J Biol Macromol 110:185-196 (2018) Available from: http://www.sciencedirect.com/science/ article/pii/S0141813017320512.

18 Fernandes R, Trindade MA, Tonin FG, Lima CG, SMP P, PES M et al., Evaluation of antioxidant capacity of 13 plant extracts by three different methods: cluster analyses applied for selection of the natural extracts with higher antioxidant capacity to replace synthetic antioxidant in lamb burgers. J Food Sci Technol 53:451-460 (2016).

19 Raghavendra SN, Rastogi NK, Raghavarao K and Tharanathan RN, Dietary fiber from coconut residue: effects of different treatments and 
particle size on the hydration properties. Eur Food Res Technol 218 : 563-567 (2004).

20 de Castro AM, dos Reis $\mathrm{CL}$ and Freire DMG, Characterization of babassu, canola, castor seed and sunflower residual cakes for use as raw materials for fermentation processes. Ind Crops Prod 83: 140-148 (2016).

21 Anjum FM, Nadeem M, Khan MI and Hussain S, Nutritional and therapeutic potential of sunflower seeds: a review. Br Food J 114:544552 (2012).

22 FEDNA, Concentrados de proteína vegetal [Internet] (2020). Available: http://www.fundacionfedna.org/concentrados_proteina_vegetal [28 December 2020].

23 Halmemies-Beauchet-Filleau A, Rinne M, Lamminen M, Mapato C, Ampapon T, Wanapat $\mathrm{M}$ et al., Alternative and novel feeds for ruminants: nutritive value, product quality and environmental aspects. Animal 12:s295-s309 (2018).

24 Tay T, Ucar S and Karagöz S, Preparation and characterization of activated carbon from waste biomass. J Hazard Mater 165:481-485 (2009).

25 Behera S, Indumathi K, Mahadevamma S and Sudha ML, Oil cakes-a by-product of agriculture industry as a fortificant in bakery products. Int J Food Sci Nutr 64:806-814 (2013).

26 Ewing WN, The Feeds Directory: Commodity Products Guide. Context Products Ltd, Publications Division, Nottingham (1997).

27 INRAE, CIRAD, AFZ, Composition and nutritive values of feeds for cattle, sheep, goats, pigs, poultry, rabbits, horses and salmonids [Internet]. (2020). Available: https://www.feedtables.com [28 December 2020].

28 Rommi K, Hakala TK, Holopainen U, Nordlund E, Poutanen K and Lantto R, Effect of enzyme-aided cell wall disintegration on protein extractability from intact and dehulled rapeseed (Brassica rapa L. and Brassica napus L.) press cakes. J Agric Food Chem 62:79897997 (2014).

29 de Castro AM, de Andréa TV, Carvalho DF, Teixeira MMP, dos Reis CL and Freire DMG, Valorization of residual agroindustrial cakes by fungal production of multienzyme complexes and their use in cold hydrolysis of raw starch. Waste Biomass Valorization 2:291-302 (2011).

$30 \mathrm{Ngoc}$ TTB, Len NT and Lindberg JE, Chemical characterization and water holding capacity of fibre-rich feedstuffs used for pigs in Vietnam. Asian-Australas J Anim Sci 25:861 (2012).

31 Geneau-Sbartaï C, Leyris J, Silvestre F and Rigal L, Sunflower cake as a natural composite: composition and plastic properties. J Agric Food Chem 56:11198-11208 (2008).

32 Knudsen KEB, Carbohydrate and lignin contents of plant materials used in animal feeding. Anim Feed Sci Technol 67:319-338 (1997).

33 Serrapica F, Masucci F, Raffrenato E, Sannino M, Vastolo A, Barone CMA et al., High fiber cakes from Mediterranean multipurpose oilseeds as protein sources for ruminants. Animals 9:918 (2019).

34 Jackson MA and Bothast RJ, Carbon concentration and carbon-tonitrogen ratio influence submerged-culture conidiation by the potential bioherbicide Colletotrichum truncatum NRRL 13737. Appl Environ Microbiol 56:3435-3438 (1990).

35 Carbonell-Capella JM, Buniowska M, Barba FJ, Esteve MJ and Frígola A, Analytical methods for determining bioavailability and bioaccessibility of bioactive compounds from fruits and vegetables: a review. Compr Rev Food Sci Food Saf 13:155-171 (2014).

36 Snezhkina AV, Kudryavtseva AV, Kardymon OL, Savvateeva MV, Melnikova NV, Krasnov GS et al., ROS generation and antioxidant defense systems in normal and malignant cells. Oxid Med Cell Longev 2019:1-17 (2019).
37 Collin F, Chemical basis of reactive oxygen species reactivity and involvement in neurodegenerative diseases. Int J Mol Sci 20:2407 (2019).

38 Tachakittirungrod S, Okonogi S and Chowwanapoonpohn S, Study on antioxidant activity of certain plants in Thailand: mechanism of antioxidant action of guava leaf extract. Food Chem 103:381-388 (2007).

39 Mohdaly AAA and Ramadan MF, Characteristics, composition and functional properties of seeds, seed cake and seed oil from different Brassica carinata genotypes. Food Biosci 100752 (2020). https://doi. org/10.1016/j.fbio.2020.100752

40 Vitcosque GL, Fonseca RF, Rodríguez-Zúñiga UF, Bertucci Neto V, Couri $S$ and Farinas CS, Production of biomass-degrading multienzyme complexes under solid-state fermentation of soybean meal using a bioreactor. Enzyme Res 2012:1-9 (2012).

41 Filipe D, Fernandes H, Castro C, Peres H, Oliva-Teles A, Belo I et al., Improved lignocellulolytic enzyme production and antioxidant extraction using solid-state fermentation of olive pomace mixed with winery waste. Biofuels Bioprod Biorefin 14:78-91 (2019).

42 Ezeilo UR, Wahab RA and Mahat NA, Optimization studies on cellulase and xylanase production by Rhizopus oryzae UC2 using raw oil palm frond leaves as substrate under solid state fermentation. Renew Energy 1301-12:156 (2019).

43 Pel HJ, De Winde JH, Archer DB, Dyer PS, Hofmann G, Schaap PJ et al., Genome sequencing and analysis of the versatile cell factory Aspergillus niger CBS 513.88. Nat Biotechnol 25:221-231 (2007).

44 Mukhtar $\mathrm{H}$, Production of acid protease by Aspergillus niger using solid state fermentation. Pak J Zool 41:253-260 (2009).

45 Verduzco-Oliva R and Gutierrez-Uribe JA, Beyond enzyme production: solid state fermentation (SSF) as an alternative approach to produce antioxidant polysaccharides. Sustainability 12:495 (2020).

46 Sánchez C, Lignocellulosic residues: biodegradation and bioconversion by fungi. Biotechnol Adv 27:185-194 (2009).

47 Sheih I, Fang TJ, Wu T and Chen R, Effects of fermentation on antioxidant properties and phytochemical composition of soy germ. J Sci Food Agric 94:3163-3170 (2014).

48 Terpinc $\mathrm{P}$, Čeh B, Ulrih NP and Abramovič $\mathrm{H}$, Studies of the correlation between antioxidant properties and the total phenolic content of different oil cake extracts. Ind Crops Prod 39:210-217 (2012).

49 Zhai F-H, Liu H-Y and Han J-R, Protein nutritional value, polyphenols and antioxidant properties of corn fermented with Agaricus brasiliensis and Agaricus bisporus. World J Microbiol Biotechnol 34:36 (2018).

$50 \mathrm{Xu}$ L-N, Guo S and Zhang S, Effects of solid-state fermentation with three higher fungi on the total phenol contents and antioxidant properties of diverse cereal grains. FEMS Microbiol Lett 365:fny163 (2018).

51 Kang M, Zhai F-H, Li X-X, Cao J-L and Han J-R, Total phenolic contents and antioxidant properties of buckwheat fermented by three strains of Agaricus. J Cereal Sci 73:138-142 (2017).

52 Sousa D, Venâncio A, Belo I and Salgado JM, Mediterranean agroindustrial wastes as valuable substrates for lignocellulolytic enzymes and protein production by solid-state fermentation. J Sci Food Agric 98:5248-5256 (2018).

53 Canedo MS, de Paula FG, da Silva FA and Vendruscolo F, Protein enrichment of brewery spent grain from Rhizopus oligosporus by solidstate fermentation. Bioprocess Biosyst Eng 39:1105-1113 (2016).

54 Salgado JM, Abrunhosa L, Venâncio A, Domínguez JM and Belo I, Integrated use of residues from olive mill and winery for lipase production by solid state fermentation with Aspergillus sp. Appl Biochem Biotechnol 172:1832-1845 (2014). 